\title{
Determination of Toxic and Trace Elements in Water Sediment and Vegetation in Topcamp Stream
}

\author{
A. C. Achudume \& S. Odoh \\ Institute of Ecology and Environmental Studies \\ Obafemi Awolowo University, Ile-Ife, Nigeria
}

Received: September 9, 2011

Accepted: October 11, $2011 \quad$ Published: January 1, 2012

doi:10.5539/ep.v1n1p69

URL: http://dx.doi.org/10.5539/ep.v1n1p69

\begin{abstract}
Human activities have continuously disturbed the natural aquatic ecosystem. The objective of the study was to determine some trace elements concentrations in water, sediments and vegetations in the impacted Topcamp stream. The study area lies between Latitudes $07^{\circ} 25^{\prime} 30^{\prime \prime} \mathrm{N}$ to $07^{\circ} 25^{\prime} 50^{\prime \prime}$ and Longitude $003^{\circ} 2^{\prime} 00^{\prime \prime}$ to $003^{\circ} 55^{\prime} 50^{\prime \prime} \mathrm{E}$, a $3 \mathrm{~km}$ stretch of freshwater within metropolitan city. Single grab of surface water and sediment samples on sequential sites were studied. Vegetation samples, syndrella modiflora, were collected in the vicinity of the stream and analyzed. Results showed that the cation ions $\mathrm{Ca}$ and $\mathrm{K}$ were in excess of normal good quality water. The values of $\mathrm{As}, \mathrm{Cu}, \mathrm{Cr}, \mathrm{Fe}$ and $\mathrm{Zn}$ were generally low and below the European Commission and WHO guidelines of drinking water quality. The trace elements concentration in the sediments, $\mathrm{As}, \mathrm{Cr}, \mathrm{Cu}, \mathrm{Fe}$, and $\mathrm{Zn}$ were elevated relative to water concentrations. The element concentrations in plant, syndrella nodiflora showed high moderate of $\mathrm{Ca}$ and $\mathrm{Mg}$, low of $\mathrm{As}, \mathrm{Cr}, \mathrm{P}$ and $\mathrm{Cd}$. Lead and $\mathrm{Cd}$ were below detection limit in water and sediment. When the sediment level of elements were compared to that of water, it is obvious that the residue levels of all heavy metals decreased indicating some capacity for assimilation.
\end{abstract}

Keywords: Human activities, Natural aquatic ecosystem, Trace elements, Vegetation, Sediment

\section{Introduction}

Increase industrialization in the past four decades has resulted in increased effluents being discharged into the aquatic system (Epko \& Ibok, 1999). These wastes are potential sources of metals in the surrounding environment. The industrial effluent generally contains high quantities of dissolved and suspended particles including toxic trace elements which cause deleterious effects on the freshwater sediments and vegetations when discharged into water bodies (Muley et al., 2007). In addition, impeded litter decomposition and soil respiration are common features of heavy metal pollution in soil (Nwuche \& Ugoji, 2008).

All heavy metals are potentially harmful to organisms at certain level of exposure and absorption. Such elements can migrate and accumulate in different components of natural ecosystems (sediments and vegetations). Most trace elements accumulate in aquatic animals and pass their toxic effects to the upper links of the trophic chain, including human beings (Yigit \& Altindag, 2006). Besides, the contamination of resources with trace elements may have devastating effect on the ecological balance of the aquatic environment with the diversity of vegetation becoming highly polluted accordance with the extent of the contamination (Karadede \& Unlu, 2000). Additionally, concentration of trace elements in sediment may render soils non productive because of phytotoxicity. In addition, impeded litter decomposition and soil respiration are common features of heavy metal polluted soils (Nwuche \& Ugoji, 2008).

Topcamp stream receives a variety of untreated wastes. Information clarifying decisions impacting toxic trace elements is important since adequate toxicity data is lacking for informed risk assessment decisions. Data on the effects of discharged effluent on vegetation is limited and magnified for contemporary developing country like Nigeria. More so, a reliable data base is required to graphically illustrate the consequences of environmental degradation and to identify opportunities to correct or avoid further deterioration.

The primary objectives of the present study were to access the chemical contaminants in water, sediments and vegetations of the impacted stream. The secondary objectives were to obtain basic and simple information permitting a better understanding of environmental impact of the heavy metals. This information would be a useful tool for effective management and control of the natural aquatic area with respect to some heavy metals that are carried and their bioavailability. 


\section{Materials and Methods}

The study area lies between latitudes $07^{\circ} 22^{\prime} 30^{\prime \prime} \mathrm{N}$ to $07^{\circ} 25^{\prime} 50^{\prime \prime}$ and longitude $003^{\circ} 2^{\prime} 00^{\prime \prime} \mathrm{E}$ to $003^{\circ} 55^{\prime} 50^{\prime \prime} \mathrm{E}$, at an altitude approximately $1500 \mathrm{~m}$ above sea level (Figure 1). The climate of the area is influenced by Tropical Maritime (mT) and Tropical Continental (cT) air masses. The mean annual rainfall is $1413 \mathrm{~mm}$, while the mean annual temperature ranges from $22.5{ }^{\circ} \mathrm{C}$ to $31.4{ }^{\circ} \mathrm{C}$. The soil in the area supports tropical rainforest vegetation, while Kaolinite is the main clay miniral present (Nwuche \& Ugoji, 2008; Adesoji \& Farinde, 2004; Salami et al., 2003). The area is located in the lowland rainforest vegetation zone of Nigeria (Keay, 1959). It is a major industrial section and various untreated or minimally treated wastes are discharged into the stream. The stream is a main lifeline of water source for the metropolitan plain. The middle reach of the stream flows through the city at average rate of 25-625 cfs apparently signaling dry season. The study period was from September 2009 to May 2010 apparently the evaluation effect of seasonal changes was taken into consideration.

Ten randomly sampling stations were established for the study $\left(\mathrm{PS}_{0}, \mathrm{PS}_{1}, \mathrm{PS}_{2}, \mathrm{PS}_{3}, \mathrm{C}_{1}, \mathrm{AC}_{1}, \mathrm{AC}_{2}, \mathrm{BC}_{0}, \mathrm{BC}_{1}\right.$, and $\mathrm{BC}_{2}$ ) thirty samples were collected, $\mathrm{n}=3$. Four of these sampling stations were established along the effluent flow (0.85-125 cfs) ( $\mathrm{PS}_{0}, \mathrm{PS}_{1}, \mathrm{PS}_{2}$, and $\left.\mathrm{PS}_{3}\right)$. One sampling station was at the confluence of the effluent flow and the adjacent Topcamp stream $\left(\mathrm{C}_{1}\right)$, three stations were along the Topcamp stream $\left(\mathrm{BC}_{0}, \mathrm{BC}_{1}\right.$ and $\left.\mathrm{BC}_{2}\right)(290-1500$ cfs) before $\mathrm{C}_{1}$ and two stations after $\left(\mathrm{AC}_{1}\right.$ and $\left.\mathrm{AC}_{2}\right)$ (230-1200 cfs). The distance between two adjacent sampling stations $\left(\mathrm{BC}_{1}, \mathrm{BC}_{2}, \mathrm{C}_{1}, \mathrm{AC}_{1}, \mathrm{AC}_{2}, \mathrm{PS}_{1}, \mathrm{PS}_{2}\right.$, and $\mathrm{PS}_{3}$ ) was $20 \mathrm{~m}$ from $\mathrm{C}_{1}$ (Figure 1). Major discharges begin immediately downstream (PSo) and flow in a steep $0.5 \mathrm{~m}$ gradient into Topcamp stream. Except in the rainy season, there is no possibility of a backflow.

Single grab samples of surface water were collected in 1-L, in acid cleaned, distilled water-rinsed brown plastic containers. Samples intended for monitoring effluents were collected from 4 sites ( $\mathrm{PSo}-\mathrm{PS}_{3}$ ) while 3 samples were collected before the mixing point $\left(\mathrm{BCo}-\mathrm{BC}_{1}\right)$ and 3 samples after $\left(\mathrm{C}_{1}-\mathrm{AC}_{3}\right)$ (Figure 1). Temperature and $\mathrm{pH}$ (corning $\mathrm{p} 5 \mathrm{pH}$ meter, accuracy \pm 0.1 ) of samples were recorded in situ. Samples were stored on ice until arrival at the laboratory and stored at $2.5{ }^{\circ} \mathrm{C}$.

For elemental analysis, water samples were filtered through $0.4<\mathrm{m} \mu>$ membrane filters acidified to a final concentration of $2 \%$ with nitric acid. Two samples were divided in half; one portion of each was spiked with known concentrations of the analytes in question in order to determine percent recovery. Blanks unspiked samples, and spiked samples were analyzed by Alpha 4 atomic absorption spectroscopy (Chem. Tech Analytical, England). The instrument was standardized frequently (every five samples with matrix-matched standards (inorganic ventures, Lakewood, NS). Standardization was verified with appropriate external standards (Spex Industries, Inc, Edison, NJ). Analyte recovery in spiked samples ranged from 92 to $100 \%$ (US EPA, 1996).

Sediment samples were collected from the sampling stations using a clean sediment auger at a depth of $0-15 \mathrm{~cm}$. Sediment samples were dried to constant weight and pulverized to fine powder. Duplicate $0.02 \mathrm{~g}$ aliquots of sediment were digested with nitric and perchloric acids until the residue (silicates) was colorless. After cooling, the volume was diluted to $50 \mathrm{ml}$ with distilled water. Blanks and sample aliquots spiked with known concentrations of analytes were included during the digestion process. Undissolved residues were allowed to settle out; digests were analyzed by Alpha atomic absorption spectrophotometer. Analyte recovery in spiked samples ranged from 90 to $100 \%$ (USEPA, 1996).

For vegetation, plant, syndrella nodiflora, samples were collected along the stream in three different sites ( $\mathrm{PSo}-\mathrm{PS}_{3}$ representing site $1, \mathrm{BC}_{1}-\mathrm{BC}_{2}$ representing site II, $\mathrm{AC}_{1}-\mathrm{AC}_{2}$ representing Site III) to the end point, while the controls were collected from the upland about two $\mathrm{km}$ away from the other sites representing the reference site $(\mathrm{BCo})$.

Ten random lines transects were laid out in each $20 \times 20 \mathrm{~m}$ sample plot, and at $1 \mathrm{~m}$ intervals along the line transect, a pin-point rod was dropped. Leaf samples were collected from 20 systematic points along each transect hit by the rod.

The leaves were washed in the laboratory and oven dried at $80{ }^{\circ} \mathrm{C}$ till constant weights stabilized. The dried samples were pulverized into a fine powder in an SNA 505 (PEPPINK DEVENTER) laboratory stainless grinder for chemical analysis. The plant samples were dried at $60{ }^{\circ} \mathrm{C}$ for $24 \mathrm{~h}$ ground and ashed in a furnace at $550{ }^{\circ} \mathrm{C}$ for $30 \mathrm{~min}$. Eight $\mathrm{ml}$ of $1 \mathrm{M} \mathrm{HCl}$ were then added to the ash. The suspension was centrifuged and the supernatant was made-up to $50 \mathrm{ml}$ with distilled water. Blanks and sample aliquots spiked with known concentration of analytes were analyzed by Alpha 4 atomic absorption spectrophometer. Analyte recovery in spiked samples ranged from $92 \%$ to $100 \%$. Cations ( $\mathrm{Ca}, \mathrm{Na}$ and $\mathrm{K}$ ) were determined using the Digital Flame Analyser. Anions $\left(\mathrm{PO}_{4}{ }^{3-}\right.$ and $\left.\mathrm{SO}_{4}{ }^{3-}\right)$ were determined using a standard analytical method (Ayas et al., 2007) and read at a wavelength of $660 \mathrm{~nm}$ and $420 \mathrm{~nm}$ respectively. Other metals (As, $\mathrm{Cr}, \mathrm{Cu}, \mathrm{Fe}, \mathrm{Mg}$ and $\mathrm{Zn}$ ) were determined 
using Alph 4 atomic spectrophotometer at wavelength of 358, 325, 248, 279, 214 and $229 \mathrm{~nm}$ respectively. Data were subjected to Barlett's test for homogeneity, followed by analysis of variance (ANOVA). For post hoc comparison Student Newman Keul's test was employed.

\section{Results}

The results obtained for the concentrations of trace elements collected from Topcamp stream are represented in Table 1 . The $\mathrm{As}, \mathrm{Ca}, \mathrm{Cr}, \mathrm{Cu}, \mathrm{Mn}$, and $\mathrm{Zn}$ values in water samples generally low and below WHO limit of toxic concentration of these elements. However, the element concentration of $\mathrm{Fe}, \mathrm{Mg}$ and $\mathrm{K}$ were relatively high considering prior filtration. The element concentrations obtained at the highest and lowest levels in the stream were observed to be $\mathrm{Fe}$ and $\mathrm{P}$ respectively. $\mathrm{Cd}$ and $\mathrm{Pb}$ were present at concentration near or below detention limits in water samples, but were detected in the plants, syndrella nodiflora (Table 3). The data in Table 1 show that the concentrations of elements in water from the study sites were much lower than those obtained from the sediment (Table 2). The order of mean concentrations in the water samples were $\mathrm{Fe}>\mathrm{K}>\mathrm{Mg}>\mathrm{Mn}>\mathrm{SO}_{4}>$ $\mathrm{Ca}>\mathrm{Na}>\mathrm{Cu}>\mathrm{Cr}>\mathrm{As}>\mathrm{Zn}>\mathrm{PO}_{4}$. Iron and $\mathrm{K}$ concentrations in water samples were found to be higher than those recommended for drinking purposes, whereas other trace metals were found to be within the toxic limits.

The results of the trace elements analysis in the sediments are shown in Table 2. Total $\mathrm{As}, \mathrm{Cr}, \mathrm{Cu}, \mathrm{Fe}$, and $\mathrm{Mn}$ concentrations in the sediment were elevated relative to water concentrations. The $\mathrm{Ca}, \mathrm{Mg}$ and $\mathrm{K}$ concentrations were surprisingly low in the sediments while $\mathrm{Cu}$ and $\mathrm{Zn}$ remained moderate in water when compared to USEPA (1977) standards for quality water.

The element concentrations in plants, syndrella nodiflora showed high moderate values of $\mathrm{Ca}$ and $\mathrm{Mg}$ and low average values of $\mathrm{As}, \mathrm{Cr}, \mathrm{Pb}$ and $\mathrm{Cd}$ (Table 3) compared to water and sediment values. The $\mathrm{Pb}$ and $\mathrm{Cd}$ which were below detection limit in water and sediment samples were detected in the plants, Site I, II and III showed higher average values compared to the reference site. The mean concentrations of $\mathrm{Ca}, \mathrm{Cu}, \mathrm{Fe}, \mathrm{Pb}$ and $\mathrm{Cd}$ were found higher in site I than those found for sites II and III while Fe and Mn were at the highest level in site III. The element levels of plant were in order as follows: $\mathrm{Fe}>\mathrm{Mg}>\mathrm{Ca}>\mathrm{Mn}>\mathrm{Cu}>\mathrm{Zn}>\mathrm{Pb}>\mathrm{Cd}$.

\section{Discussion}

The predominant cations in both water and sediment samples were $\mathrm{Ca}$ and $\mathrm{K}$, while $\mathrm{Cu}, \mathrm{Fe}, \mathrm{Mg}$, and $\mathrm{Mn}$ are major elements in both samples (Table 1 and 2). The presence of $\mathrm{As}, \mathrm{Cr}, \mathrm{K}, \mathrm{P}, \mathrm{Pb}$ and $\mathrm{Zn}$ suggest that the stream contains many cations, all from processes of raw materials. Generally, there is increased level of measured parameters in water (Table 1) and sediment (Table 2) samples, indicating some capacity for assimilation and perhaps especially, dilution by up stream water parts of Topcamp stream by heavy rain. The pollutions from industries in the region are transported to the downstream which significantly impacted the stream with $\mathrm{Mg}, \mathrm{Fe}$, $\mathrm{K}, \mathrm{Mg}, \mathrm{Mn}$ and $\mathrm{Ca}$ (Table 1) while $\mathrm{Cu}, \mathrm{Fe}$, and $\mathrm{Mg}$ in the sediments (Table 2), and $\mathrm{Fe}, \mathrm{Mg}, \mathrm{Ca}, \mathrm{Cu}, \mathrm{Mn}$ and $\mathrm{Zn}$ in vegetation (Table 3). The values observed for $\mathrm{As}(3.60 \mathrm{mg} / \mathrm{l})$ in station $\mathrm{BC}_{0}$ is significant $(\mathrm{p}<0.01>$ compared to $\mathrm{PS}_{0}$ whereas, those of $\mathrm{Mg}$ in stations $\mathrm{BC}_{1}(38.90 \mathrm{mg} / \mathrm{l})$ and $\mathrm{BC}_{2}(42.14 \mathrm{mg} / \mathrm{l})$ are obviously as a result of capacity for backflow and /or some other discharge point from unknown source (Table 1). Similarly, the values of $\mathrm{Fe}$ and $\mathrm{Mn}$ in $\mathrm{BC}_{1}$ and $\mathrm{BC}_{2}$ in the sediment (Table 2) may follow the same trend as reported above.

The concentrations of heavy metals like $\mathrm{As}, \mathrm{Cu}, \mathrm{Cr}, \mathrm{Cd}, \mathrm{Pb}$ and $\mathrm{Zn}$ in water samples were below or near detection limits as a result of adsorption and accumulation of elements by suspended solids while the concentration of elements in the sediments were higher than those found in the water column. When the sediment levels of the elements are compared to that of water, it is clearly seen that the residue levels of the trace elements decreased after sequential sites (Table 1 and 2). There was poor vegetation growth along the stream and erosion could possibly be an important factor for increased sedimentation. Erosion subsequently transfers the sediment elements from their point of origin into freshwater systems. As was observed by Champon (1992), sediments may then be re-suspended and transported further until it comes to its ultimate resting point or sink where active sediment accumulation occurs. Therefore, it can be concluded that sediments containing the absorbed elements may be deposited along the stretch of the stream. Similarly, it can be deduced that the residue levels in the sediments decreased due to sedimentation caused by shore line erosion.

It is evident from the Table 1 and 2 that most of the toxic elements in the vegetation, Syndrella nodiflora, originated from the water and sediments. The plants accumulated sufficient levels of $\mathrm{Cu}, \mathrm{Fe}, \mathrm{Mg}, \mathrm{Mn}, \mathrm{Zn}$ and Cation $\mathrm{Ca}$ as reflected in site 1,2 and 3 compared to the reference site. Increased urbanization in the area has led (through housing or road construction and industries in particular) to increase in water pollution. Water from the stream is often used for various purposes such as watering of livestock, vegetable gardens and other domestic uses, including car washing. These occur by direct extraction or pumping close to the stream resulting in increased content of potassium from detergents. Industrial activities and solid waste disposal may lead to 
increase trace elements and acidification of water bodies. Exposure to sub-lethal doses of these trace elements will reduce the population of vulnerable organisms and vegetations by mortality or decreasing growth rate (Groot et al., 2002). Some ecological factors such as dissolved oxygen, salinity and detritus have a significant effect on both absorption and bioaccumulation of metals (Karadede-Akin \& Ünlü, 2007). The partition coefficient for metal concentrations in water and sediment environment and in crab tissue was determined as 0.05 .

Finally, trace element levels of Topcamp stream are generally increasing by domestic and industrial effluent discharge. By international standard Topcamp stream is comparable to many other streams in the world, except perhaps, morphological conditions such as attitude, geology setting, size and depth. Given the same level of trace elements, and unified classification systems for the assessment of water quality based on ecological indicators. Topcamp stream compares favourably with European Commission DG Environment 2000/6, USEPA water quality control 1977 and WHO 1984 Guidelines of Drinking Water Quality.

Inclusion, metal pollution in Topcamp stream is not at a level to affect human health directly, but may adversely affect aquatic life. According to the present results, the heavy metals were deposited in the sediments and accumulated in the crabs. These crabs, syndrella nodiflora, are endemic species and have a special importance in means of biodiversity. In addition, pollution levels from Associated Match Industry discharging into Topcamp stream have a potential threat on birds and associated wildlife in the region. Management and other stakeholders' should focus actions on restoring or preserving the natural flow of Topcamp stream. Conservation measures should also include efforts to reduce polluting substances, because these will certainly have a negative effect on the aquatic organisms in the long term.

\section{References}

APHA. (2005). Standard methods for examination of water and waste water. $21^{\text {st }}$ Ed. ALPHA, AWWA, WFF, Washington D.C.

Adesoji, S.A., \& Farinde, A.J. (2004). Factors associated with the productivity of arable crop farmers in Osun State Nigeria. International Journal of Biological, Physiological Sciences, 8, 57-62.

Ayas, Z., Ekmeka, G., Yerli, S.V., \& Ozmen, M. (2007). Heavy metal accumulation in water, sediments and fishes of Nallihan Bird Paradise Turkey. Journal Environmental Biology, 28, 545-549.

Canli, M.A.O., \& Kalay, M. (1998). Levels of heavy metals (Cd, $\mathrm{Pb}, \mathrm{Cu}, \mathrm{Cr}$ and $\mathrm{Ni}$ ) in tissue of Cyprinus Carpio, Barbers Capilo and Chondrostoma regium from the Seyhan river, Turkey. Trend Journal of Zoology, 22, 149-157.

Chapman, D. (1992). Water Quality Assessment. A guide to biota, sediments and water in environment monitoring. Chapman and Hall Publishing, Cambridge, 35, pp.

Ekpo, B.O., \& Ibok, U. J. (1999). Temporal variation and distribution of trace metals in freshwater and Fish

from Caliber river, S.E. Nigeria. Environmental Geochemical Health, 21, 51-66. http://dx.doi.org/10.1023/A:1006544711923

Groot, R.S., Wilson, M.A., \& Boumans, R.M.J. (2002). A typology for the classification, description and valuation of ecosystem functions, goods and services. Ecol. Econ., 41, 393-408. http://dx.doi.org/10.1016/S0921-8009(02)00089-7

Karadede, H., \& Ünlü, E. (2000). Concentrations of some heavy metals in water sediment and fish species from the Ataurk dam lake (Euphrates). Turkiye. Chemosphere, 41, 1371-1376. http://dx.doi.org/10.1016/S0045-6535(99)00563-9

Karadede-Akin, H., \& Ünlü, E. (2007). Heavy metal concentrations in water, sediment, fish and some benthic organisms from Tigris River, Turkey. Environmental Monitoring and Assessment, 131, 323-337. http://dx.doi.org/10.1007/s10661-006-9478-0

Keay, R.W.J. (1959). An outline of Nigeria vegetation, $3^{\text {rd }}$ ed. Federal Government Printer, Lagos.

Muley, D.V., Karanjkor, D.M., \& Maske, S.V. (2007). Impact of Industrial Effluents on the biochemical composition of freshwater fish Labeo rohita. Journal Enviromental Biology, 28, 245-249.

Nwuche, C.O., \& Ugoji, E.O. (2008). Effects of heavy metal pollution on the soil microbial activity. Int. J. Environ. Sci. Tech., 5, 409-414.

Salami, A.T., Jimoh, M.A., \& Muoghalu, J.I. (2003). Impact of Gold mining on vegetation and soil in Southwestern Nigeria. Int. J. Environ. Studies, 60, 343-352. http://dx.doi.org/10.1080/00207230304731 
USEPA. (1977). Quality criteria for water. Office of water and Hazardous materials, US Environmental Protection Agency, Washington, DC, 56 pp.

USEPA. (1996). Acid digestion of sediments, sludge's and soils. Method 3050B.

WHO. (1984). Guidelines of Drinking Water Quality in Health Criteria and other supporting information, 2,336 pp.

Yigit, S., \& Altindag, A. (2006). Concentration of heavy metals in the food web of lake Egirdir, Turkey. $J$. Environ. Biol., 27, 475-478.

Table 1. Concentrations $(\mathrm{Mg} / \mathrm{L})$ of toxic and essential elements in water collected in Topcamp Stream

\begin{tabular}{c|cccccccccccccc}
\hline & $A s$ & $C a$ & $C d$ & $C r$ & $C u$ & $F e$ & $M g$ & $M n$ & $P b$ & $Z n$ & $S_{\boldsymbol{O}_{4}}$ & $P_{4}$ & $K$ & $N \boldsymbol{a}$ \\
\hline $\mathbf{P S}_{\mathbf{0}}$ & 1.40 & 34 & $\mathrm{BDL}$ & 9.07 & 2.63 & 19.20 & 45.82 & 2.79 & $\mathrm{BDL}$ & $<0.05$ & 7.53 & 0.42 & 11.50 & 41 \\
$\mathbf{P S}_{\mathbf{1}}$ & 0.00 & 30 & $\mathrm{BDL}$ & 0.58 & 5.64 & $673.70^{*}$ & 51.43 & 31.06 & $\mathrm{BDL}$ & 5.41 & 2.05 & 2.05 & $490^{*}$ & 25 \\
$\mathbf{P S}_{\mathbf{2}}$ & 0.60 & 36 & $\mathrm{BDL}$ & 1.57 & 3.69 & 306.70 & 58.03 & 32.49 & $\mathrm{BDL}$ & 4.04 & 24.24 & 24.24 & $710^{*}$ & 29 \\
$\mathbf{P S}_{\mathbf{3}}$ & $<0.05$ & 40 & $\mathrm{BDL}$ & 1.84 & 3.22 & $1128.30^{*}$ & 47.13 & 45.48 & $\mathrm{BDL}$ & $<0.05$ & 43.91 & 43.91 & $675^{*}$ & 28 \\
$\mathbf{C}_{\mathbf{1}}$ & $<0.05$ & 30 & $\mathrm{BDL}$ & 0.31 & 1.86 & $749.50^{*}$ & 48.57 & 10.33 & $\mathrm{BDL}$ & 0.56 & 30.51 & 30.51 & $205^{*}$ & 16 \\
$\mathbf{A C}_{\mathbf{1}}$ & $<0.05$ & 28 & $\mathrm{BDL}$ & 0.19 & 2.46 & 61.00 & 44.77 & 5.16 & $\mathrm{BDL}$ & $\mathrm{BDL}$ & 41.63 & 41.63 & 130 & 11 \\
$\mathbf{A C}_{\mathbf{2}}$ & 0.20 & 24 & $\mathrm{BDL}$ & 0.35 & 3.25 & 25.80 & 43.88 & 0.03 & $\mathrm{BDL}$ & $\mathrm{BDL}$ & 29.38 & 29.38 & 125 & 17 \\
$\mathbf{B C}_{\mathbf{0}}$ & 3.60 & 08 & $\mathrm{BDL}$ & $\mathrm{BDL}$ & $\mathrm{BDL}$ & 9.30 & 1.93 & 0.50 & $\mathrm{BDL}$ & 0.85 & 0.24 & 0.24 & $175^{*}$ & 2.6 \\
$\mathbf{B C}_{\mathbf{1}}$ & $<0.05$ & 08 & $\mathrm{BDL}$ & 0.12 & 1.47 & $<0.05$ & 38.90 & 0.11 & $\mathrm{BDL}$ & 2.64 & 19.95 & 19.96 & 95 & 8.25 \\
$\mathbf{B C}_{\mathbf{2}}$ & $<0.05$ & 18 & $\mathrm{BDL}$ & 0.19 & $\mathrm{BDL}$ & $\mathrm{BDL}$ & 42.14 & $\mathrm{BDL}$ & $\mathrm{BDL}$ & $\mathrm{BDL}$ & 33.65 & 33.65 & 40 & 9.60 \\
\hline
\end{tabular}

BDL Below detention limit $<0.01 \mathrm{ppm}$. All values are mean of triplicate \pm S.D ANOVA.

*Significance $\mathrm{P}<0.01$ compare to site $\mathrm{PS}_{0}$.

Table 2. Physical and chemical characterization of sediment samples collected from sequential sites in Topcamp stream in $\mathrm{mg} / \mathrm{kg}$

\begin{tabular}{|c|c|c|c|c|c|c|c|c|c|c|c|c|c|c|c|}
\hline & $\%$ sand & $\%$ silt & $\%$ clay & $\begin{array}{c}\% \\
\text { organic } \\
\text { matter }\end{array}$ & As & $\mathrm{Ca}$ & $C d$ & $\mathrm{Cr}$ & $\mathrm{Cu}$ & $\mathrm{Fe}$ & $K$ & $M g$ & $M n$ & $\mathrm{~Pb}$ & $Z n$ \\
\hline $\mathbf{P S}_{0}$ & 74.00 & 9.00 & 17.00 & 4.99 & BDL & 6.04 & BDL & 3.80 & 649.58 & $10,769.00$ & 0.35 & 18.75 & 257.70 & BDL & 2.70 \\
\hline $\mathbf{P S}_{1}$ & 92.00 & 5.00 & 3.00 & 0.34 & 1.00 & 5.49 & BDL & 13.98 & 767.42 & $268,544.60^{*}$ & 4.06 & 10.55 & 23.17 & $\mathrm{BDL}$ & 2.40 \\
\hline $\mathbf{P S}_{2}$ & 94.00 & 3.00 & 3.00 & 0.17 & 2.00 & 2.32 & BDL & 46.90 & 635.83 & $72.347 .42 *$ & 0.50 & 8.48 & 3234.00 & BDL & 0.20 \\
\hline $\mathbf{P S}_{3}$ & 92.00 & 5.00 & 3.00 & 4.47 & 36.00 & 3.28 & BDL & 21.48 & 560.00 & $166,713.62 *$ & 4.37 & 8.75 & 13.81 & BDL & $\mathrm{BDL}$ \\
\hline $\mathrm{C}_{0}$ & 76.00 & 3.00 & 21.00 & 4.99 & 1.00 & 3.09 & $\mathrm{BDL}$ & 32.30 & 577.42 & $27,295.00$ & 0.92 & 8.04 & $1,301.70$ & $\mathrm{BDL}$ & BDL \\
\hline $\mathrm{AC}_{1}$ & 86.00 & 5.00 & 9.00 & 5.50 & 0.60 & 8.39 & BDL & 2.20 & 577.08 & $12,335.00$ & 1.26 & 10.21 & 913.80 & BDL & 0.40 \\
\hline $\mathrm{AC}_{2}$ & 92.00 & 5.00 & 3.00 & 0.34 & 1.00 & 7.15 & BDL & 1.70 & 745.00 & $141,789.04 *$ & 1.01 & 13.98 & $6,135.00^{*}$ & BDL & 2.50 \\
\hline $\mathrm{BC}_{0}$ & 94.00 & 3.00 & 3.00 & 0.86 & 36.36 & 0.80 & BDL & BDL & $\mathrm{BDL}$ & 90.75 & 0.05 & 7.21 & 1.69 & BDL & $\mathrm{BDL}$ \\
\hline $\mathrm{BC}_{1}$ & 78.00 & 9.00 & 13.00 & 2.06 & BDL & 5.46 & BDL & 70.20 & 512.50 & $67.605^{*}$ & 0.54 & 9.58 & $2,589.10^{*}$ & BDL & 0.10 \\
\hline $\mathrm{BC}_{2}$ & 76.00 & 13.00 & 11.00 & 0.86 & BDL & 10.24 & $\mathrm{BDL}$ & 86.30 & 758.75 & $168,169.01 *$ & 2.72 & 9.20 & 9.283 .60 & $\mathrm{BDL}$ & BDL \\
\hline
\end{tabular}

BDL Below detention limit $<0.01 \mathrm{ppm}$. All values mean of triplicate \pm S.D. ANOVA.

* Significance $\mathrm{P}<0.05$ compare to $\mathrm{BC}_{0}$. 
Table 3. Concentrations $(\mathrm{Mg} / \mathrm{kg})$ of toxic and essential elements in plant, syndrella nodiflora from the Topcamp Stream

\begin{tabular}{c|cccccccccc}
\hline Site & $A s$ & $C a$ & $M g$ & $C r$ & $C u$ & $F e$ & $P b$ & $M n$ & $C d$ & $Z n$ \\
\hline Site & BDL & 607.20 & 1805.10 & BDL & 375.63 & $11,331.00$ & 0.75 & 216.09 & 0.345 & 27.00 \\
Site & BDL & 493.50 & 2427.00 & BDL & 350.00 & 3186.00 & BDL & 344.10 & 0.120 & 85.20 \\
Site & 1.500 & 456.30 & 2340.90 & BDL & 108.45 & 4813.38 & 0.15 & 404.55 & 0.015 & BDL \\
Reference site & BDL & 39.32 & 86.49 & BDL & 6.12 & 11.2 & BDL & 2.95 & BDL & 5.63 \\
\hline Mean & & 519.00 & 2191.00 & BDL & 278.03 & 6443.46 & 0.45 & 321.58 & 0.16 & 56.10 \\
Min. & & 456.20 & 1805.10 & BDL & 108.45 & 0.15 & 216.09 & 0.015 & 0.015 & 27.00 \\
Max. & & 607.20 & 2427.00 & BDL & 375.63 & $11,331.00$ & 0.75 & 404.55 & 0.345 & 85.20 \\
\hline
\end{tabular}

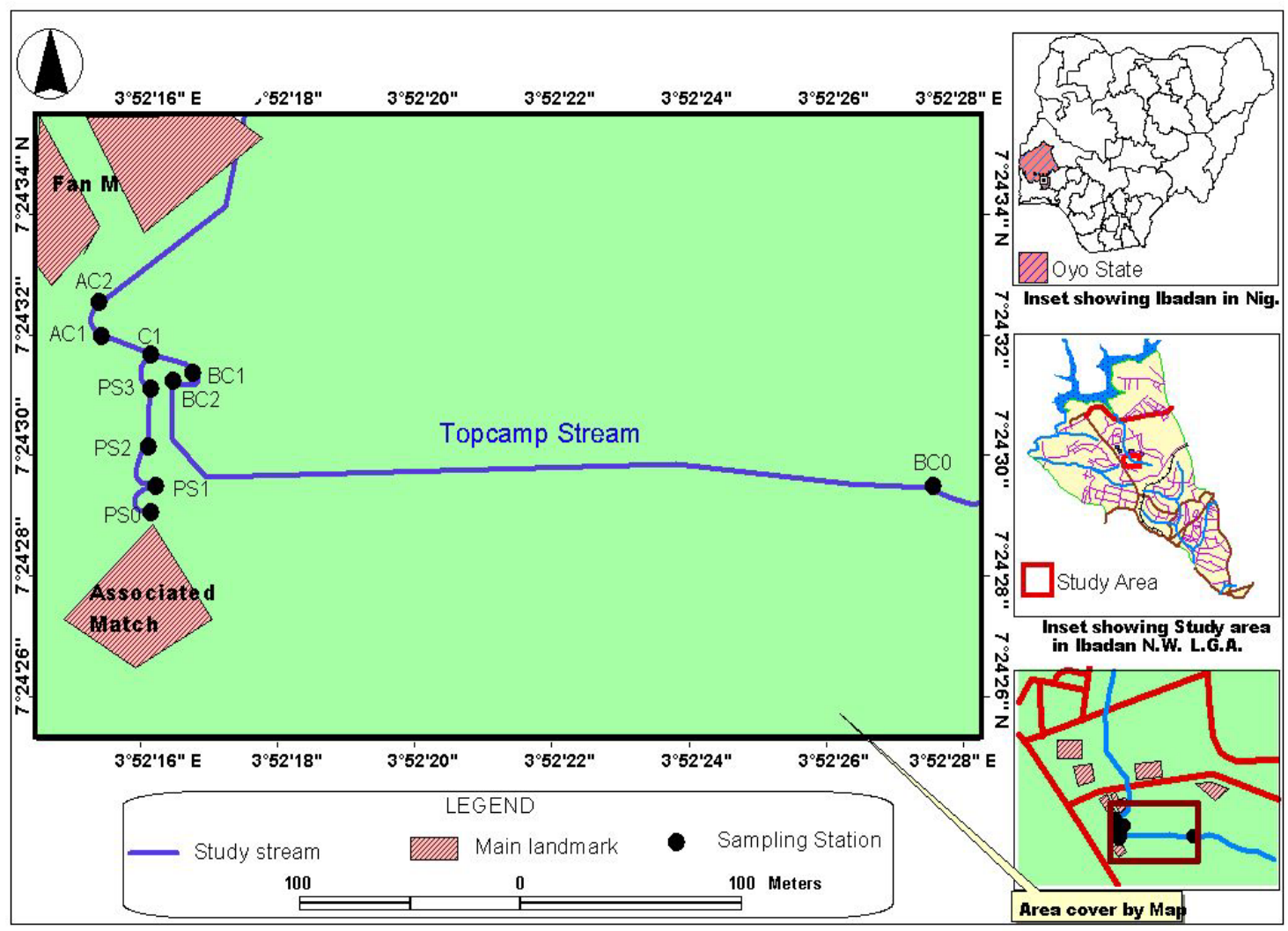

Figure 1. Detailed Map of Study Area showing Sampling Stations 